\title{
Evaluation of Cytotoxicity and Apoptotic behavior of Cerium Oxide/Zinc Oxide/ Graphene Oxide in HeLa and VERO cell Lines
}

saranya J ( $\sim$ saranyaa23@gmail.com )

Rajalakshmi Engineering College, Thandalam

\section{BS Sreeja}

SSN College of Engineering, Kalavakkam

\section{Arivanandan}

Anna University

\section{K Bhuvaneswari}

SSN College of Engineering, Kalavakkam

\section{S Sherin}

Rajalakshmi Engineering College, Thandalam

\section{K S Shivani}

Rajalakshmi Engineering College, Thandalam

\section{K K Saroja}

Rajalakshmi Engineering College, Thandalam

\section{G SaradhaPreetha}

Rajalakshmi Engineering College, Thandalam

\section{Research Article}

Keywords: Nanocomposite, HeLa cells, Cervical cancer, CeO2/ZnO/GO nanosystem, Flow cytometry, Fluorescence microscopy

Posted Date: August 30th, 2021

DOI: https://doi.org/10.21203/rs.3.rs-823008/v1

License: (c) (i) This work is licensed under a Creative Commons Attribution 4.0 International License. Read Full License 


\section{Abstract}

Using the ultrasonic approach, we produced a morphology involving cerium oxide/ Zinc oxide/graphene oxide $\left(\mathrm{CeO}_{2} / \mathrm{ZnO} / \mathrm{GO}\right)$ nanocomposite-based system. The developed nanocomposite was examined using X-Ray diffraction (XRD), Fourier transform infrared spectroscopy (FTIR), and field emission scanning electron microscopy (FESEM). The average crystallite size was found to be $11.44 \mathrm{~nm}$, as determined by XRD. FTIR analysis was used to confirm the existence of functional groups. FESEM was used to verify the morphological properties of $\mathrm{CeO}_{2} / \mathrm{ZnO} / \mathrm{GO}$. The micromorphology of $\mathrm{CeO}_{2} / \mathrm{ZnO} / \mathrm{GO}$ nanocomposite reveals a smoother sheet-like structure. In addition, using an antiproliferative assay test, the developed nanosystem was evaluated for its scavenging anti-cancer capability against HeLa cell lines at various doses and incubation intervals. In our investigation, the effective IC50 concentration was reported to be $62.5 \mu \mathrm{g} / \mathrm{ml}$ at $72 \mathrm{~h}$. Further, the developed nanosystem was evaluated for its killing efficacy against normal cell line. To identify apoptosis-associated alterations of cell membranes throughout the apoptosis process, a dual acridine orange/ethidium bromide (AO/EB) fluorescent staining was done using $\mathrm{CeO} 2 / \mathrm{ZnO} / \mathrm{GO}$ nanocomposite at three specific concentrations. The quantitative analysis was carried out using flow cytometry (FACS study) to determine the cell cycle during which the greatest number of HeLa cells were destroyed. According to the results of the FACS investigation, maximum cell cycle has taken place in $\mathrm{P} 2$, P4.As a result, the newly designed $\mathrm{CeO} / \mathrm{ZnO} / \mathrm{GO}$ hybrid has demonstrated improved anti-cancer efficacy against the HeLa cell line, making it a better therapeutic agent for cervical cancer detection.

\section{Introduction}

Cervical cancer has a global incidence rate of 13.1/105 and a death rate of 6.9/105, respectively. In India, cervical cancer is the second most frequent cancer among women, with an estimated 96,922 new cases and 60,078 deaths. Although the incidence and death rates vary among the Indian population, they are $14.7 / 105$ and $9.2 / 105$, respectively. The majority of these cervical patients appear at a late stage of disease in a health-care facility due to a lack of knowledge (1). As a result, research into the toxicity of various types of nanomaterials has confirmed the feasibility of diagnosing cancer. Various nanoparticle formulations for diagnostic and therapeutic purposes have been developed as a result of recent breakthroughs in nanotechnology. Diagnostic nanoparticles are designed to aid in the visualization of pathologies and the better understanding of important (patho-) physiological principles underlying a variety of diseases and treatments. However, due to the complicated demands on their pharmacokinetic characteristics and elimination, nano-diagnostics are only helpful in a restricted number of clinical settings. As a result, the vast majority of nanoparticle formulations employed in clinics today are for therapeutic purposes (2). Particle size and charge, core and surface properties, shape and flexibility, multivalency and controlled synthesis, as well as multivalency and controlled synthesis, are the most important properties of nanoparticle formulations, as they determine the nanoparticle's in vivo distribution, targeting ability, and toxicity. Furthermore, these characteristics have a significant impact on drug loading capacity and release, as well as nanoparticle stability $(3,4,5)$. Metal oxide NPs (MONPs), in 
particular, have several advantages, including high stability, simple preparation processes, easy engineering to the desired size, shape, and porosity, no swelling variations, easy incorporation into hydrophobic and hydrophilic systems, and easy functionalization by various molecules due to the negative charge of the surface, all of which make them a promising tool for biomedical applications (6). Different cell target specificity exhibits varying metabolic activity and, as a result, varying cell death processes and sensitivity to MONP exposure. When nano SiO2 NPs were compared to the toxic effects of human monocytes (THP-1) and human lung epithelial cells (L-132), it was discovered that THP-1 cells were more cytotoxic than L-132 cells (7). Metal oxide nanosystems with semiconducting characteristics, such as titanium dioxide $\left(\mathrm{TiO}_{2}\right)$, zirconium dioxide $\left(\mathrm{ZrO}_{2}\right)$, copper-II oxide ( $\left.\mathrm{CuO}\right)$, zinc oxide $(\mathrm{ZnO})$, and cerium oxide $\left(\mathrm{CeO}_{2}\right)$ in various morphologies, help to provide biological potencies $(8,9)$. Because of its large band gap ( $3.19 \mathrm{eV}$ ), cerium oxide is an outstanding semiconductor oxide. Because of its antioxidative and anti-inflammatory capabilities, $\mathrm{CeO}_{2}$ nanoparticles (NPs) have sparked interest in the biomedical area $[13,14]$. Researchers are currently working on GO/RGO-based nanocomposites that have better optoelectronic properties than pure GO or RGO. Also, Graphene is a two-dimensional sheet of sp2 hybridized carbon atoms that has a variety of features, including elasticity, flexibility, high conductivity, and ease of functionalization [8, 9]. Graphene has sparked a lot of interest in synthetic biology and nanomedicine, in addition to its uses in photonics, optoelectronics, and environmental remediation [1012].Furthermore, because of its anti-inflammatory, antibacterial, and antifungal properties, the use of $\mathrm{ZnO}$ in medicine is particularly promising, as evidenced by the development of special textiles for patients with chronic inflammatory skin illnesses [15]. Also, in vitro, ZnO-NP coupled with chemotherapeutic medicines shown specific anti-cancer efficacy [16]. However, studies on combining the properties of cerium oxide, zinc oxide and graphene oxide nanoparticles has not yet been explored. This prompted us to study anticancer and apoptotic activity of $\mathrm{CeO}_{2} / \mathrm{ZnO} / \mathrm{GO}$ nanocomposite. In addition, we have also experimented anticancer effectiveness upon loading cisplatin (anticancer drug) in the developed $\mathrm{CeO}_{2} / \mathrm{ZnO} / \mathrm{GO}$ platform. X-Ray diffraction (XRD) was used to examine their physio-chemico characteristics, field emission scanning electron microscopy (FESEM) was used to examine their morphological properties, and FTIR was used to validate the presence of functional groups. Their crystalline, morphological, and functional existences gave a great track record in anticancer experiments against HeLa cell lines, and they are addressed in more detail below.

\section{Materials And Methods}

All chemicals and solvents were of analytical grade and were utilized without being purified further. Fischer Scientifc in India provided cerous nitrate hexahydrate $\left(\mathrm{CeN}_{3} \mathrm{O}_{9} \cdot 6 \mathrm{H}_{2} \mathrm{O}\right)$, graphene oxide $(\mathrm{GO})$ and sodium hydroxide $(\mathrm{NaOH})$. Zinc acetate dihydrate $\mathrm{Zn}\left(\mathrm{CH}_{3} \mathrm{COO}\right)_{2} \cdot 2 \mathrm{H}_{2} \mathrm{O}(99.5 \%)$, Acetone $\mathrm{CH}_{3} \mathrm{CHO}(99 \%)$ was acquired from Sisco Research Laboratories Pvt. Ltd (SRL)-India. The CeO2/GO hybrid nanosystem's X-Ray difraction (XRD) spectrum was captured using a RIGAKU mini fux 2C, Japan. The functional groups found in the product were analyzed using the spectrum of Fourier infrared spectroscopy (JASCO FT-IR-6300, Japan)..Surface morphology was obtained using a Carl Zeiss NTS GMBH FESEM model 
SUPRA 55. A spectrophotometer (Labman Scientific Instruments, India) was used to collect absorption spectra. Metzer Inverted Confocal Microscope, India, was used to obtain confocal pictures of HeLa cells.

\subsection{In vitro investigation on anticancer efficacy using $\mathrm{CeO}_{2} / \mathrm{ZnO} / \mathrm{GO} \& \mathrm{CeO} / \mathrm{CDDP}-\mathrm{ZnO} / \mathrm{GO}$ system}

The cellular toxicity of $\mathrm{CeO}_{2} / \mathrm{ZnO} / \mathrm{GO}$ hybrid (blank) and $\mathrm{CeO}_{2} / \mathrm{CDDP}-\mathrm{ZnO} / \mathrm{GO}$ system (cisplatin loaded porous hybrid nanosystem) was investigated in cancer cell lines (HeLa). The cells were kept in a humidified atmosphere of $50 \mathrm{\mu g} / \mathrm{ml} \mathrm{CO}_{2}$ at $37^{\circ} \mathrm{C}$ for 24 hours in Minimal Essential Medium supplemented with $10 \% \mathrm{FBS}$, penicillin $(100 \mathrm{U} / \mathrm{ml})$, and streptomycin $(100 \mu \mathrm{g} / \mathrm{ml})$. The cells were removed from the cell culture flasks using trypsin-EDTA when they reached 95 percent confluence. The cell solution was centrifuged for 5 minutes at $900 \mathrm{rpm}$ before being resuspended in culture media at a concentration of $1 \times 105$ cells $/ \mathrm{mL}$.In each well of a transparent flat bottom 96-well plate (Costar), $200 \mu \mathrm{l}$ of the cell suspension was transferred and incubated for 24 hours. After that, the medium was withdrawn and replaced with fresh medium containing 2-fold serial dilutions. A methylthiazolyldiphenyltetrazolium bromide (MTT) viability experiment was used to assess the toxicity of the porous hybrid nanosystem. A total of $5 \mathrm{mg}$ of MTT was mixed in $1 \mathrm{~mL}$ PBS solution and then diluted 10 times in culture medium. After removing the supernatants, $100 \mu \mathrm{L}$ of MTT solution was added to each well, which was then incubated for 4 hours before adding $100 \mu \mathrm{L}$ of the solubilization solution (anhydrous isopropanol containing $0.1 \mathrm{~N}$ $\mathrm{HCl}$ and 10 percent Triton X-100).After that, the plates were incubated overnight and the absorbance was measured on a microplate reader at $570 \mathrm{~nm}$ (BMG FLUO star OPTIMA). Non-treated cells (M) in culture medium were assumed to be 100 percent viable (live cells). The following formula was used to compute the percent cell inhibition:

$$
\% \text { Cell inhibition }=\frac{\text { O.D value of treated cells using hybrid nanosystem }}{\text { O.D value of non-treated cells }} \times 100
$$

When the CeO2/CDDP- ZnO/GOsystem was interacted with the HeLa cell line under in - vitro conditions, the same approach was used to determine the percent Cell inhibition for the purpose of estimation of its synergetic effect with the anticancer drug. Finally, based on the data collected, the sample concentration required to achieve $50 \%$ cell inhibition was calculated and recorded as the IC50 value. This IC50 value will be used as a benchmark for further research into the anti-cancer potential of our $\mathrm{CeO}_{2} / \mathrm{ZnO} / \mathrm{GO}$ hybrid system.

\subsection{Apoptosis Study using Direct Fluorescence Microscopic Analysis}

The morphological induction of apoptosis on the $\mathrm{CeO}_{2} / \mathrm{ZnO} / \mathrm{GO}$ hybrid nanocomposite treated cells was detected by acridine orange/ ethidium bromide (AO/EB) staining. The cells were fixed for 1 hour at room temperature in a 3:1 mixture of ethanol and phosphate buffer solution (PBS). The cells treated with hybrid nanocomposite were incubated after being labeled with a 1:1 ratio of $A O$ and EB in PBS. After washing away the excess unbinding dye with PBS, the stained cells were examined under a fluorescence microscope. 


\subsection{Cell cycle Analysis}

The cell cycle arrest was tested using procedure [40], in which $(1 \times 106)$ cells were cultivated in a tissue culture dish and allowed to mature for the entire night. The cells were preserved as controls after being treated with $\mathrm{CeO}_{2} / \mathrm{ZnO} / \mathrm{GOcomplexes}$. The cells were trypsinized and collected in appropriate centrifugal tubes after reaching 75 percent confluence. The cells in the pellet were then re-suspended in $300 \mathrm{~mL}$ of phosphate buffer solution-ethylenediamine tetra acetic acid (PBS-EDTA) to which $700 \mathrm{~mL}$ of cold $70 \%$ ethanol was added drop-wise with gradual mixing after centrifugation at $2500 \mathrm{rpm}$ for 5 minutes at room temperature (RT).The solution was added to guarantee $100 \%$ ethanol combination, and the samples were stored overnight at $0{ }^{\circ} \mathrm{C}$. Following that, 100 I RNase $A$ was added to the cell suspension and incubated for 1 hour at $37^{\circ} \mathrm{C} .400$ I propidium iodide was added to the stain and let to sit at room temperature for 10-20 minutes in the dark. A flow cytometer was used to examine the labeled cells for cell phase distribution.

\subsection{Preparation of $\mathrm{CeO}_{2} / \mathrm{ZnO} / \mathrm{GO}$ hybrid nanocomposite}

In a recent article, we described the procedure for making $\mathrm{CeO}_{2}$ nano-particles and $\mathrm{CeO}_{2} / \mathrm{GO}$ hybrid nanocomposite (28). ZnO nanoparticle was prepared by using simple wet chemical route in which $1.2 \mathrm{~g}$ of Zinc acetate dihydrate was stirred along with $0.4 \mathrm{~g}$ of sodium hydroxide (41). Further, $1 \mathrm{~g}$ of $\mathrm{CeO}_{2} \mathrm{NPs}$ powder was diluted in $100 \mathrm{ml}$ distilled water and ultrasonically processed for 30 minutes. $1 \mathrm{~g}$ of GO NPs powder was diluted in $100 \mathrm{ml}$ distilled water and ultrasonically processed for 2 hours. $0.5 \mathrm{~g}$ of ZnO nanoparticleswas diluted in $50 \mathrm{ml}$ distilled water and ultrasonically processed for 30 minutes. Finally, the three mixture-containing solutions are blended to create a nanocomposite solution. Furthermore, after combining the mixtures, they were stirred for 2 hours to achieve a homogenous solution. After allowing the materials to settle, they were cleaned three times with distilled water as shown in fig 1 .

\section{Results \& Discussions}

\subsection{X-ray Diffraction Study}

Figure 2 shows the XRD pattern of the $\mathrm{CeO}_{2} / \mathrm{ZnO} / \mathrm{GO}$ nanocomposite samples. The X-Ray diffraction pattern of the $\mathrm{CeO} / \mathrm{ZnO} / \mathrm{GO}$ composite shows the characteristic peaks of at $2 \theta=27.01,32.22$, $45.27,54.7,60.0,69.52$ and $76^{\circ}$ corresponding to the lattice planes (111),(200),(220), (311), (222), (400) and (311) respectivelywhich were well matched withthe JCPDS card no. 65-5923 associated to the $\mathrm{CeO}_{2}$ cubic face centered crystal system(18). The observed XRD pattern shows that $\mathrm{CeO}_{2}$ is in high concentration compared to other nanoparticles. Crystallite size of the prepared sample was calculated by Scherrer equation (Eq. 1) and the average crystallite size is around $11.44 \mathrm{~nm}$ (19)(20). The d spacing values of the important peaks were calculated by Bragg's equation (Eq. 2) and the obtained values are $0.33,0.22,0.20,0.17$ and $0.15 \mathrm{~nm}$ for the corresponding lattice planes of (111), (200), (220), (311) and (222) respectively. The observed result confirms that the formation of nanocomposite. 


\subsection{FTIR study}

Inorder toidentified the functional groups, transmittance in the infrared (IR) region takesplace(4000-500 $\mathrm{cm}^{-1}$ ) due to the vibrationalandrotational movement of the chemical bond and molecular groups of the prepared sample. The observed FTIR result of the prepared sample was given in figure 3 which shows that various functional groups were present in the sample. the observed various functional group can be due to the presence of $\mathrm{CeO}_{2}, \mathrm{ZnO}$ and $\mathrm{GO}$ particles. The band at $3373.71 \mathrm{~cm}^{-1}$ corresponds to the- $\mathrm{OH}$ stretching vibrations of the hydroxyl groups which may be observed due to the surface observed water molecules(21).Moreover, otherbands observed at 2919.42, 1454.28, and $1097.65 \mathrm{~cm}^{-1}$, correspondingto the band reflection of $\mathrm{C}-\mathrm{H}, \mathrm{C}=\mathrm{O}$, and $\mathrm{C}-\mathrm{Ostretching} \mathrm{vibrations,} \mathrm{respectively} \mathrm{which} \mathrm{confirms} \mathrm{the} \mathrm{presence} \mathrm{of}$ $\mathrm{GO}$ in the composite sample(22)(23)(24). Similarly, the band observed $1631 \mathrm{~cm}^{-1}$ correspond tohydrogen-bonded O-H groups of water molecules(25). The observed bands at $608.18 \mathrm{~cm}^{-1}$ and 837.75 $\mathrm{cm}^{-1}$ could be owed to the envelope of phonon band of the metal oxygen stretching vibrations(26). Hence the FTIR results clearly confirms the formation of $\mathrm{GO}$ with $\mathrm{M}-\mathrm{O}\left(\mathrm{CeO}_{2} / \mathrm{ZnO}\right)$.

\subsection{Surface Morphology Study}

Figure 4 shows the representative morphological structure of the $\mathrm{Ce}_{2} / \mathrm{ZnO} / \mathrm{GO}$ nanocompositerevealed by the FE-SEM images. In figure 3 the micro morphology of $\mathrm{CeO}_{2} / \mathrm{ZnO} / \mathrm{GO}$ nanocompositeshows smoother sheet-likestructure. Particularly, the existence of a GO sheets comprised of folded and wrinkled sheets like structure. In figure 3 (b) the appearance of a minorrough structure on the wrinkle surface shows that the $\mathrm{CeO}_{2} / \mathrm{ZnO}$ nanoparticles has been effectivelyattached on the surface of GOto the residual oxygen-containing functional groupsthe $\mathrm{GO}(27)$. From this observed FE-SEM image the growth of $\mathrm{CeO}_{2} / \mathrm{ZnO}$ nanoparticles can be seen on the surfaceof $\mathrm{GO}$ sheets which eventually increase the surface area of the as prepared nanocomposites.

\subsection{In-vitro cytotoxicity evaluation of $\mathrm{CeO2/ZnO/GO}$ and CeO2/CDDP-ZnO/GO systemson HeLa cells and normal cells}

HeLa cells were treated with $\mathrm{CeO}_{2} / \mathrm{ZnO} / \mathrm{GO}$ nanocomposite and \% cell viability was recorded after day 1 \& day 3 ( 24 hrsand $72 \mathrm{hrs}$ ) as shown in figure 5 . Further, developed nanocomposite was subject to noncancerous cell line (VERO) and its killing effect on normal cells were recorded after $24 \mathrm{hrs}$. Here cell viability refers to the number of $\mathrm{HeLa}$ cancer cells that stay alive after interacting with $\mathrm{CeO}_{2} / \mathrm{ZnO} / \mathrm{GO}$ hybrid that has been developed. These cytotoxicity assays were often carried out at various concentration levels $(1000,500,250,125,62.5,31.2,15.6$ and $7.8 \mu \mathrm{g} / \mathrm{ml})$ of materials at varying incubation intervals $(24,48$, and 72 hours) in order to obtain an accurate IC50 value for which nearly $50 \%$ of malignant cells were destroyed. IC50 refers to the lowest concentration of developed nanomaterial at which almost half of the HeLa cell line remains alive while the rest dies. In our investigation, $500 \mu \mathrm{g} / \mathrm{ml}$ was determined to be the IC50 value, indicating that cell viability was nearing $50 \%$ for 24 hours and it is $62.5 \mu \mathrm{g} / \mathrm{ml}$ for 72 hours. The MTT results show that as the concentration of our produced $\mathrm{CeO}_{2} / \mathrm{ZnO} / \mathrm{GO}$ hybrid increases, 
the number of dead cells increases while the number of living cells decreases. When a maximum concentration of about $1000 \mu \mathrm{g} / \mathrm{ml}$ of $\mathrm{CeO}_{2} / \mathrm{ZnO} / \mathrm{GO}$ hybrid was targeted on HeLa cell line for 72 hours, \%cell death was recorded to 81.82 percent, while the least concentration of about $7.8 \mu \mathrm{g} / \mathrm{ml}$ of $\mathrm{CeO}_{2} / \mathrm{ZnO} / \mathrm{GO}$ hybrid were applied to the HeLa cell line, it resulted in decreased cell death by about 16.89 percent. The antiproliferative experimentation was carried out in this work for two different incubation periods ( $24 \mathrm{hrsand} 72 \mathrm{hrs}$ ), and the effective IC50 concentration was reported to be $62.5 \mu \mathrm{g} / \mathrm{ml}$ at $72 \mathrm{~h}$ (Fig. 5). In addition, when a maximum concentration of $1000 \mu \mathrm{g} / \mathrm{ml}$ of $\mathrm{CeO}_{2} / \mathrm{ZnO} / \mathrm{GO}$ hybrid were targeted on normal cells \% live cells was 67.74 and for lowest concentration of $7.8 \mu \mathrm{g} / \mathrm{ml}$ it was $96.77 \%$ as shown in fig 6 . These findings show that developed $\mathrm{CeO}_{2} / \mathrm{ZnO} / \mathrm{GO}$ hybrid platform is potent to kill HeLa cells and possess less toxicity on normal cells. Previous studies (28) on HeLa cells using $\mathrm{CeO}_{2} / \mathrm{GO}$ hybrid nanoparticles in various concentrations and incubation durations found similar effects. The inhibition rate was found to be $88.89 \%$. Also, (29) demonstrated $\%$ cell viability of $\mathrm{CeO}_{2} / \mathrm{ZnO}$ hybrid with maximum attainment of $95.44 \%$ and ZnO NPs with $90.48 \%$ against HeLa cells. Based on these findings, $\mathrm{CeO}_{2} / \mathrm{ZnO} / \mathrm{GO}$ hybrid were combined with cisplatin and was subject to antiproliferative assay to record their synergetic biomolecular interactions. Fig 5 reveals that, when a maximum concentration of 1000 $\mu \mathrm{g} / \mathrm{ml}$ of $\mathrm{CeO}_{2} / \mathrm{CDDP}-\mathrm{ZnO} / \mathrm{GO}$ were interacted with HeLa cell line, $95.47 \%$ cells were killed and for $7.8 \mu \mathrm{g} / \mathrm{ml}$ it was $59.35 \%$. This further affirms the ability of $\mathrm{CeO}_{2} / \mathrm{ZnO} / \mathrm{GO}$ hybrid to act as drug delivery platform. The electrostatic interaction between the nanocomposite and the cell lines may have caused a reduction in the cytotoxicity effects, resulting in a lower rate of death with extended incubation time (32). The nonspecific surface reactivity had a hatching rate that was proportional to the concentration. The $\mathrm{CeO}_{2} / \mathrm{ZnO} / \mathrm{GO}$ hybrid nanocomposite demonstrated stronger cytotoxicity effects against HeLa cells than previously reported $\mathrm{CeO}_{2}$ nanoparticles $(33,34)$ when tested for anticancer activities. The \%cell inhibition rate induced by interacting cerium oxide nanoparticles, zinc oxide NPs and the hybrids against various cancer cell lines was compared to previously published results and is summarized in Table 1.

Table 1: Comparative analysis of different NPs \& hybrids against different cell lines

\begin{tabular}{|llllc|}
\hline $\begin{array}{l}\text { S. } \\
\text { No }\end{array}$ & Materials Developed & $\begin{array}{l}\text { Types of cell line } \\
\text { used }\end{array}$ & $\begin{array}{l}\text { \% Cell } \\
\text { Inhibition }\end{array}$ & References \\
\hline 1. & $\mathrm{CeO}_{2} / \mathrm{ZnO}$ & $\mathrm{HeLa}$ & 95.44 & 12 \\
\hline 2. & $\mathrm{CeO}_{2} / \mathrm{GO}$ & $\mathrm{HeLa}$ & 88.89 & 11 \\
\hline 3. & $\mathrm{ZnO} \mathbf{N P s}$ & $\mathrm{HeLa}$ & 90.48 & 12 \\
\hline 4. & $\mathrm{CeO}_{2} \mathrm{NPs}$ & $\mathrm{A} 549$ & $\sim 15$ & 13 \\
\hline 5. & $\begin{array}{l}\text { DOX-loaded nanoceria } \\
\left(\mathrm{CeO}_{2} / \text { DOX) }\right.\end{array}$ & $\mathrm{A} 2780$ & 63.32 & 14 \\
\hline
\end{tabular}


The induced $\%$ cell death upon interaction of $\mathrm{CeO}_{2} / \mathrm{ZnO} / \mathrm{GO}$ hybrid with HeLa cell line was further subject to qualitative analysis using AO/EB Dual Staining study which was performed at different concentrations such as $1000 \mu \mathrm{g} / \mathrm{ml}, 500 \mu \mathrm{g} / \mathrm{ml}$ and $250 \mu \mathrm{g} / \mathrm{ml}$.

\subsection{Apoptotic study on $\mathrm{CeO}_{2} / \mathrm{ZnO} / \mathrm{GO}$ nanocomposite using AO/EB Dual Staining}

The morphological and synergetic biochemical alterations when $\mathrm{CeO}_{2} / \mathrm{ZnO} / \mathrm{GO}$ nanocomposite was interacted with HeLa cells were explored further. The AO stain can enter both living and apoptotic cells, emitting green fluorescence, while the EB stain can only enter necrotic cells, emitting red fluorescence (3637). Red fluorescence was generated by apoptotic cells which includes only dead cells (35). The morphological changes due to interaction of $\mathrm{CeO}_{2} / \mathrm{ZnO} / \mathrm{GO}$ hybrid with HeLa cells were recorded and is shown in Fig 7. Fig 7a shows untreated HeLa cells which emits green fluorescence due to absorption of AO by live cancer cells. Fig $7 \mathrm{~b}$ shows red fluorescence due to absorption of EB by dead cancer cells and this happened due to interaction of maximum concentration of $1000 \mu \mathrm{g} / \mathrm{ml} \mathrm{of} \mathrm{CeO}_{2} / \mathrm{ZnO} / \mathrm{GO}$ with HeLa cells. Fig 7(c,d) shows presence of few green fluorescence amidst large red fluorescence and this happened due to interaction of $500 \mu \mathrm{g} / \mathrm{ml}$ and $250 \mu \mathrm{g} / \mathrm{mlCeO}_{2} / \mathrm{ZnO} / \mathrm{GO}$ nanocomposite with HeLacells.All these findings affirms that the developed $\mathrm{CeO}_{2} / \mathrm{ZnO} / \mathrm{GO}$ hybrid possess good anti-cancer properties against HeLa cells. Further, quantitative analysis was performed on developed system to evaluate apoptotic behavior using flow cytometry study.

\subsection{Flow Cytometry Analysis}

The cell cycle at which the most cancer cells were killed was estimated using $\mathrm{CeO}_{2} / \mathrm{ZnO} / \mathrm{GO}$ hybrid formulations at various concentrations $(125 \mu \mathrm{g} / \mathrm{ml}, 31.2 \mu \mathrm{g} / \mathrm{ml}$, and $62.5 \mu \mathrm{g} / \mathrm{ml})$ using flow cytometry as shown in figure 8(a-d).Their anticancer efficacy was estimated using cellular uptake study using monolayer cell culture model. Fig 8(a) reveals flow cytometry of untreated HeLa cells with $\mathrm{p} 1$ highly populated. Fig 8 (b-d) shows the flow cytometry upon interaction of $125 \mu \mathrm{g} / \mathrm{ml}, 62.5 \mu \mathrm{g} / \mathrm{ml}$ and 31.2 $\mu \mathrm{g} / \mathrm{ml}$ concentration of $\mathrm{CeO}_{2} / \mathrm{ZnO} / \mathrm{GO}$ hybrid on $\mathrm{HeLa}$ cells. These findings affirms that maximum cell cycle has taken place in P2, P4 events. In addition, among all these concentrations, IC50 concentration of $62.5 \mu \mathrm{g} / \mathrm{ml}$ was able to arrest maximum cancer cells across 4 phase cycles ( $1, \mathrm{p} 2, \mathrm{p} 3, \mathrm{p} 4)$. significant cell cycle arrest was generated as a result of increased cytotoxicity, which then caused apoptotic behavior at an early stage (Child phase). Furthermore, as the IC50 concentration was increased, the peak intensity in the $\mathrm{p} 3 \mathrm{cycle}$ decreased, indicating better cell death. The intensity changes are related to the surface charged characteristics, and we saw a similar impact in our previous $\mathrm{CeO}_{2} / \mathrm{GO}$ hybrid work (28). Culcasi et al. demonstrated that pretreatment of human dermal and murine 3T3 fibroblasts with the CONP dosedependently triggered the release of superoxide dismutase and catalase-inhibitable 5-

(diethoxyphosphoryl)-5-methyl-1-pyrroline-N-oxide/hydroxyl radical adducts (DEPMPO-OH) and ascorbyl radical in the culture medium using DEPMPO spin trapping of hydroxyl radical in an EPR study. This reaction is thought to be mediated by both mitochondrial activation and the NADPH oxidase complex, according to the researchers. The findings backed with a twofold mechanistic explanation for oxidative 
stress caused by CONP exposure, with an early signaling at micromolar concentrations modulated by thiol-containing molecules (38). Also, the prooxidant activity of the nanoparticles is partly responsible for the alterations in intracellular redox state generated by CONP. Furthermore, cell damage caused by ROS may finally result in cell death (39). Aside from these porous and crystalline properties, our hybrid system has paved the road for it to operate as an ideal hydrophilic surface, allowing it to collect the maximum cancer cells and enhance \%cell inhibition.

\section{Conclusion}

In conclusion, an ultrasonic approach was used to create $\mathrm{CeO}_{2} / \mathrm{ZnO} / \mathrm{GO}$ nanocomposite. The average size of crystallites was discovered to be $11.44 \mathrm{~nm}$. XRD and FTIR measurements were used to establish the physiochemical properties. FESEM was used to investigate the surface morphology of the produced nanocomposite. The anticancer properties of the developed $\mathrm{CeO}_{2} / \mathrm{ZnO} / \mathrm{GO}$ platform were later validated utilizing cytotoxicity, apoptosis, and flow cytometry. Antiproliferative assay was also used to test the synergetic impact of the synthesized hybrid and cisplatin, an anticancer medication. These findings support the use of the $\mathrm{CeO}_{2} / \mathrm{ZnO} / \mathrm{GO}$ hybrid system in cervical cancer screening and diagnosis.

\section{Declarations}

\section{Declaration of interests}

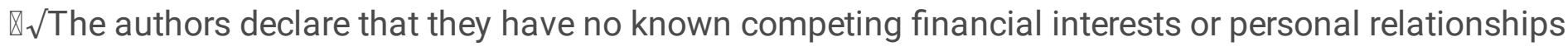
that could have appeared to influence the work reported in this paper.

छxThe authors declare the following financial interests/personal relationships which may be considered as potential competing interests:

\section{J. Sarang}

\section{References}

1. Ganesh Balasubramaniam, Rajshree H. Gaidhani, Arshi Khan, SushamaSaoba, Umesh Mahantshetty, AmitaMaheshwari 2020, 'Survival rate of cervical cancer from a study conducted in India', Indian journal of Medical Sciences', doi: 10.25259/IJMS_140_2020.

2. Sarah C. Baetke, Twan Lammers, Fabian Kiessling 2015, 'Applications of nanoparticles for diagnosis and therapy of cancer', The British Journal of RadiologyVol. 88, No. 1054, Doi:https://doi.org/10.1259/bjr.20150207

3. Sumer B, Gao J. Theranostic nanomedicine for cancer. Nanomedicine. 2008;3:137-40. 
4. Longmire MR, Ogawa M, Choyke PL, Kobayashi $\mathrm{H}$. Biologically optimized nanosized molecules and particles: more than just size. Bioconjug Chem. 2011;22(6):993-1000. 78.

5. Grimm J, Scheinberg DA. Will nanotechnology influence targeted cancer therapy? Semin Radiat Oncol. 2011;21(2):80-7.

6. Sánchez-Moreno, P.; Ortega-Vinuesa, J.L.; Peula-García, J.M.; Marchal, J.A.; Boulaiz, H. Smart DrugDelivery Systems for Cancer Nanotherapy. Curr. Drug Targets 2016, 17, 339-359. [CrossRef]

7. Sahu, D.; Kannan, G.M.; Tailang, M.; Vijayaraghavan, R. In Vitro Cytotoxicity of Nanoparticles: A Comparison between Particle Size and Cell Type. J. Nanosci. 2016, 2016, 4023852. [CrossRef]

8. K. McNamara, S.A.M. Tofail, Nanoparticles in biomedical applications. Adv. Phys. X 2, 54-88 (2017) 7. H. Sharma, P.K. Mishra, S. Talegaonkar, B. Vaidya, Metal nanoparticles: a theranostic nanotool against cancer. Drug Discov. Today 20, 1143-1151 (2015)

9. Geim, A.K. Graphene: Status and prospects. Science 2009, 324, 1530-1534. [CrossRef]

10. Lalwani, G.; D’Agati, M.; Khan, A.M.; Sitharaman, B. Toxicology of graphene-based nanomaterials. Adv. Drug. Deliv. Rev. 2016, 105, 109-144. [CrossRef]

11. Palacios, T. Graphene electronics: Thinking outside the silicon box. Nat. Nanotechnol. 2011, 6, 464465. [CrossRef] [PubMed]

12. Krishnan, D.; Kim, F.; Luo, J.; Cruz-Silva, R.; Cote, L.J.; Jang, H.D.; Huang, J. Energetic graphene oxide: Challenges and opportunities. Nano Today 2012, 7, 137-152. [CrossRef]

13. Zhang, B.; Wei, P.; Zhou, Z.; Wei, T. Interactions of graphene with mammalian cells: Molecular mechanisms and biomedical insights. Adv. Drug. Deliv. Rev. 2016, 105, 145-162. [CrossRef] [PubMed]

14. Hirst, S.M.; Karakoti, A.S.; Tyler, R.D.; Sriranganathan, N.; Seal, S.; Reilly, C.M. Anti-inflammatory properties of cerium oxide nanoparticles. Small 2009, 5, 2848-2856. [CrossRef]

15. Akhtar, M.J.; Ahamed, M.; Alhadlaq, H.A.; Khan, M.A.M.; Alrokayan, S.A. Glutathione replenishing potential of $\mathrm{CeO} 2$ nanoparticles in human breast and fibrosarcoma cells. J. Colloid Interface Sci. 2015, 453, 21-27. [CrossRef] [PubMed]

16. Wiegand, C.; Hipler, U.C.; Boldt, S.; Strehle, J.; Wollina, U. Skin-protective effects of a zinc oxidefunctionalized textile and its relevance for atopic dermatitis. Clin. Cosmet. Investig. Derm. 2013, 6, 115-121.

17. Pairoj, S.; Damrongsak, P.; Damrongsak, B.; Jinawath, N.; Kaewkhaw, R.; Ruttanasirawit, C.; Leelawattananon, T.; Locharoenrat, K. Antitumor activities of carboplatin-doxorubicin-zno complexes in different human cancer cell lines (breast, cervix uteri, colon, liver and oral) under uv exposition. Artif. Cells Nanomed. Biotechnol. 2021, 49, 120-135. [CrossRef] [PubMed].

18. Zhang, Q. P., Xu, X. N., Liu, Y. T., Xu, M., Deng, S. H., Chen, Y., Yuan, H., Yu, F., Huang, Y., Zhao, K., Xu, S. and Xiong, G. (2017) A feasible strategy to balance the crystallinity and specific surface area of metal oxide nanocrystals. Sci. Rep.7, 1-12. https://doi.org/10.1038/srep46424. 
19. Ogundare, O. D., Akinribide, O. J., Adetunji, A. R., Adeoye, M. O. and Olubambi, P. A. (2019) Crystallite size determination of thermally deposited Gold Nanoparticles. Procedia Manuf.30, 173-179. https://doi.org/10.1016/j.promfg.2019.02.025.

20. Liu, J., Lv, G., Gu, W., Li, Z., Tang, A. and Mei, L. (2017) A novel luminescence probe based on layered double hydroxides loaded with quantum dots for simultaneous detection of heavy metal ions in water. J. Mater. Chem. C5, 5024-5030. https://doi.org/10.1039/c7tc00935f.

21. Parimi, D., Sundararajan, V., Sadak, O., Gunasekaran, S., Mohideen, S. S. and Sundaramurthy, A. (2019) Synthesis of Positively and Negatively Charged CeO2 Nanoparticles: Investigation of the Role of Surface Charge on Growth and Development of Drosophila melanogaster. ACS Omega4, 104-113. https://doi.org/10.1021/acsomega.8b02747.

22. Kumari, S., Sharma, P., Yadav, S., Kumar, J., Vij, A., Rawat, P., Kumar, S., Sinha, C., Bhattacharya, J., Srivastava, C. M. and Majumder, S. (2020) A Novel Synthesis of the Graphene Oxide-Silver (GO-Ag) Nanocomposite for Unique Physiochemical Applications. ACS Omega5, 5041-5047. https://doi.org/10.1021/acsomega.9b03976.

23. Ahmad, M. A., Aslam, S., Mustafa, F. and Arshad, U. (2021) Synergistic antibacterial activity of surfactant free Ag-GO nanocomposites. Sci. Rep.11, 1-9. https://doi.org/10.1038/s41598-02080013-w.

24. Ickecan, D., Zan, R. and Nezir, S. (2017) Eco-Friendly Synthesis and Characterization of Reduced Graphene Oxide. J. Phys. Conf. Ser.902. https://doi.org/10.1088/1742-6596/902/1/012027.

25. Ghule, K., Ghule, A. V., Chen, B. J. and Ling, Y. C. (2006) Preparation and characterization of ZnO nanoparticles coated paper and its antibacterial activity study. Green Chem.8, 1034-1041. https://doi.org/10.1039/b605623g.

26. Jayakumar, G., Irudayaraj, A. A. and Raj, A. D. (2019) Investigation on the synthesis and photocatalytic activity of activated carbon-cerium oxide (AC-CeO2) nanocomposite. Appl. Phys. A Mater. Sci. Process.125, 1-9. https://doi.org/10.1007/s00339-019-3044-4.

27. Benjwal, P., Kumar, M., Chamoli, P. and Kar, K. K. (2015) Enhanced photocatalytic degradation of methylene blue and adsorption of arsenic(iii) by reduced graphene oxide (rGO)-metal oxide (TiO2/Fe304) based nanocomposites. RSC Adv.5, 73249-73260. https://doi.org/10.1039/c5ra13689j.

28. J. Saranya, B. S. Sreeja, G. Padmalaya, S. Radha \& T. Manikandan 2019, 'Ultrasonic Assisted Cerium Oxide/Graphene Oxide Hybrid: Preparation, Anti-proliferative, Apoptotic Induction and G2/M Cell Cycle Arrest in HeLa Cell Lines', Journal of Inorganic and Organometallic Polymers and Materials, volume 30, pages2666-2676.

29. J. Saranya, B. S. Sreeja, G. Padmalaya, S. Radha \& M. Arivanandan 2021, 'Microwave Thermally Assisted Porous Structured Cerium Oxide/Zinc Oxide Design: Fabrication, Electrochemical Activity Towards Pb lons, Anticancer Assessment in HeLa and VERO Cell Lines', Journal of Inorganic and Organometallic Polymers and Materials, volume 31, pages1279-1292. 
30. S. Mittal, A. Pandey, Cerium oxide nanoparticles induced toxicity in human lung cells: role of ROS mediated DNA damage and apoptosis. Biomed. Res. Int. (2014). https://doi. org/10.1155/2014/891934.

31. J. Das, Y.-J. Choi, J. Han, M. Abu Musa, T. Reza, J.-H. Kim, Nanoceria-mediated delivery of doxorubicin enhances the antitumourefciency in ovarian cancer cells via apoptosis. Sci. Rep. 7, 9513 (2017).

32. E. Montiel-Eulef, T. Jara, M. Garcés, P. Leal, Cytotoxic efect of double emulsion (W/O/W) CuSO4 loaded PLA nanoparticles on MKN-45 gastric adenocarcinoma cell line. Int. J. Morphol. 32, 61-69 (2014).

33. R. Gupta, H. Xie, Nanoparticles in daily life: applications, toxicity and regulations. J. Environ. Pathol. Toxicol. Oncol. 37, 209-230 (2018)

34. R. Wahab, F. Khan, A. Gupta, H. Wiggers, Q. Saqui, M. Faisal, S. Ansari, Microwave plasma-assisted silicon nanoparticles: cytotoxic, molecular, and numerical responses against cancer cells. RSC Adv. 9, 13336-13347 (2019).

35. E. Nourmohammadi, H. Khoshdel-sarkarizi, R. Nedaeinia, H.R. Sadeghnia, L. Hasanzadeh, M. Darroudi, R. Kazemioskuee, Evaluation of anticancer efects of cerium oxide nanoparticles on mouse fbrosarcoma cell line. J. Cell. Physiol. 234(4), 4987-4996 (2019)

36. S. Mittal, A. Pandey, Cerium oxide nanoparticles induced toxicity in human lung cells: role of ROS mediated DNA damage and apoptosis. Biomed. Res. Int. (2014). https://doi. org/10.1155/2014/891934

37. J. Das, Y.-J. Choi, J. Han, M. Abu Musa, T. Reza, J.-H. Kim, Nanoceria-mediated delivery of doxorubicin enhances the antitumourefciency in ovarian cancer cells via apoptosis. Sci. Rep. 7, 9513 (2017)

38. M. Culcasi, L. Benameur, A. Mercier, C. Lucchesi, H. Rahmouni, A. Asteian, G. Casano, A. Botta, H. Kovacic, S. Pietri, EPR spin trapping evaluation of ROS production in human fibroblasts exposed to cerium oxide nanoparticles: evidence for NADPH oxidase and mitochondrial stimulation, Chem. Biol. Interact. 199 (2012) 161-176.

39. MilicaPešic, Ana Podolski-Renic, Sonja Stojkovic ,BrankoMatovic, Danica Zmejkoski , Vesna Kojic, Gordana Bogdanovic , Aleksandra Pavicevic, MilošMojovic , Aleksandar Savic, Ivana Milenkovic, Aleksandar Kalauzi , KsenijaRadotic 2015, ' Anti-cancer effects of cerium oxide nanoparticles and its intracellular redox activity' Chemico-Biological Interactions, volume. 232, 85-93.

40. PeishengXu, Edward A. Van Kirk, William J. Murdoch, Yihong Zhan, Dale D. Isaak, Maciej Radosz, YouqingShen (2006) Anticancer Efficacies of Cisplatin-Releasing pH-Responsive Nanoparticles. Biomacromolecules 7: pp. 829-835

41. Padmalaya. G, B.S. Sreeja, P. selvakumar, A. Arivanandan 2017, “ Chitosan anchored Zinc oxide nanocomposite as modified electrochemical sensor for the detection of $\mathrm{Cd}(\mathrm{II})$ ions, Desalination and water treatment, vol.97, pp no. 295-303. 
Figures
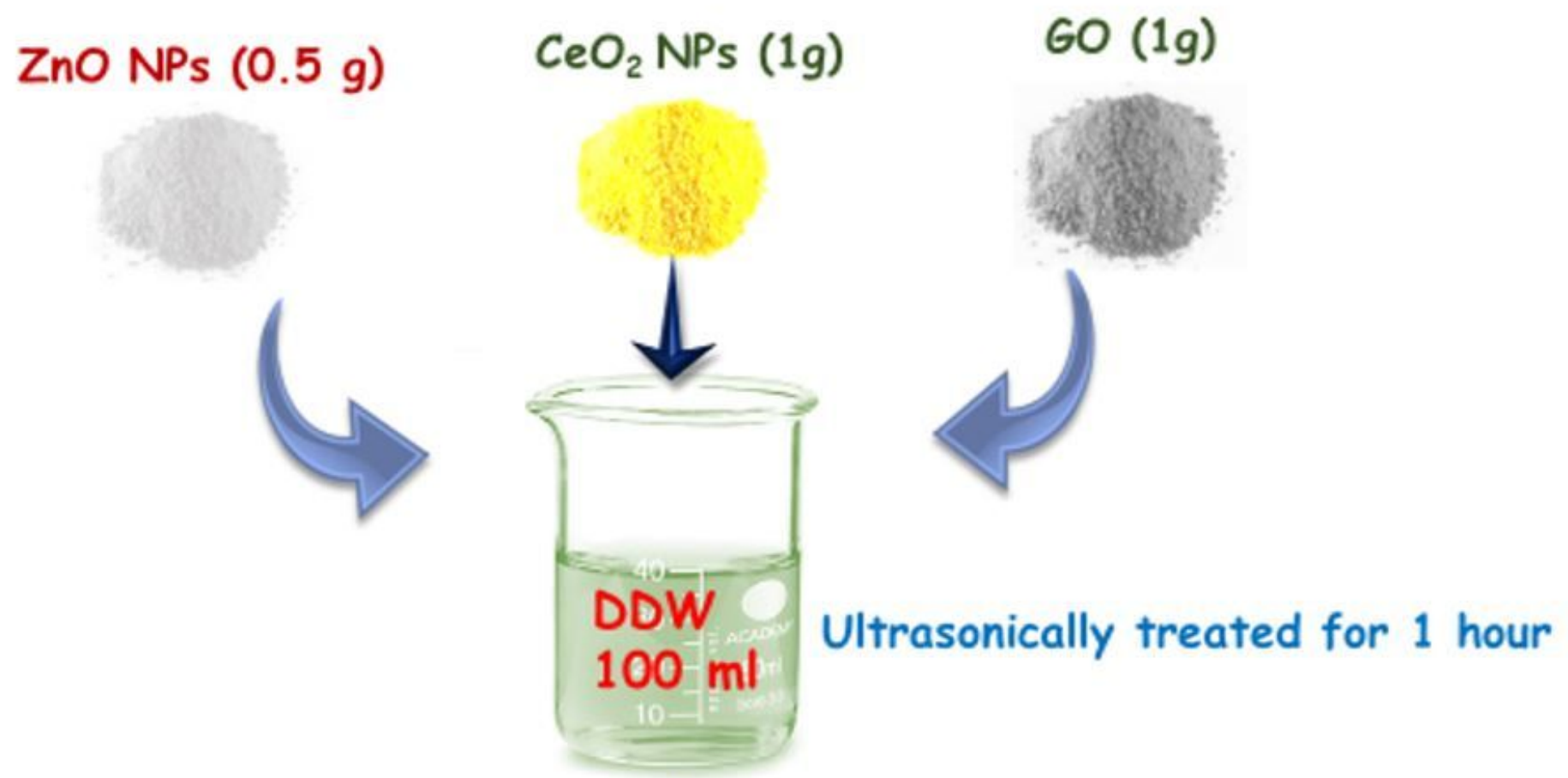

\section{Stirred 2 hrs}

\section{$\mathrm{CeO}_{2} / \mathrm{ZnO} / \mathrm{GO}$ hybrid nanocomposite}

Figure 1

Schematic view of the synthesis steps in the development of a CeO2/ZnO/GO nanocomposite 


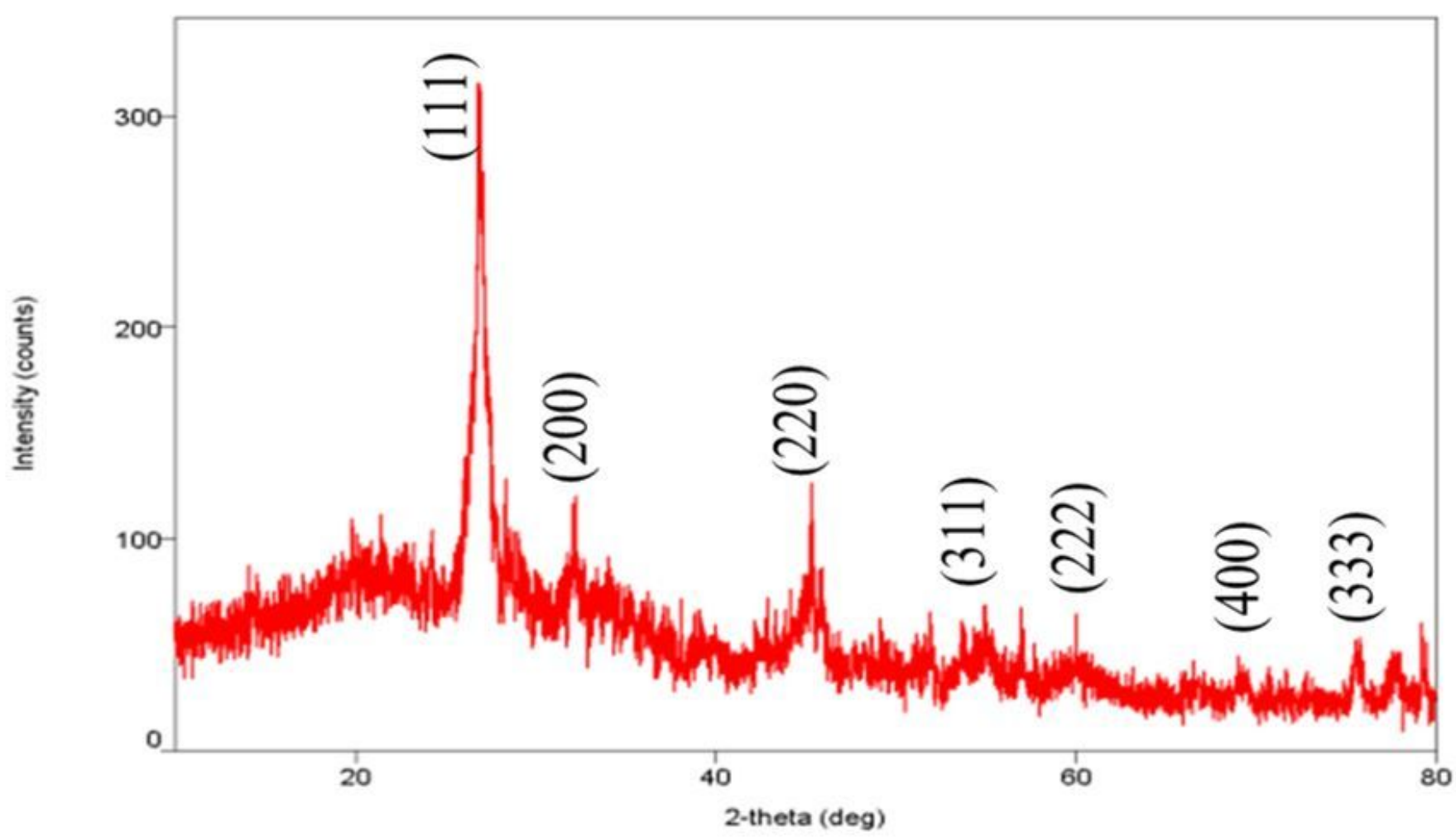

Figure 2

XRD pattern of $\mathrm{CeO} / \mathrm{ZnO} / \mathrm{GO}$ nanocomposite 


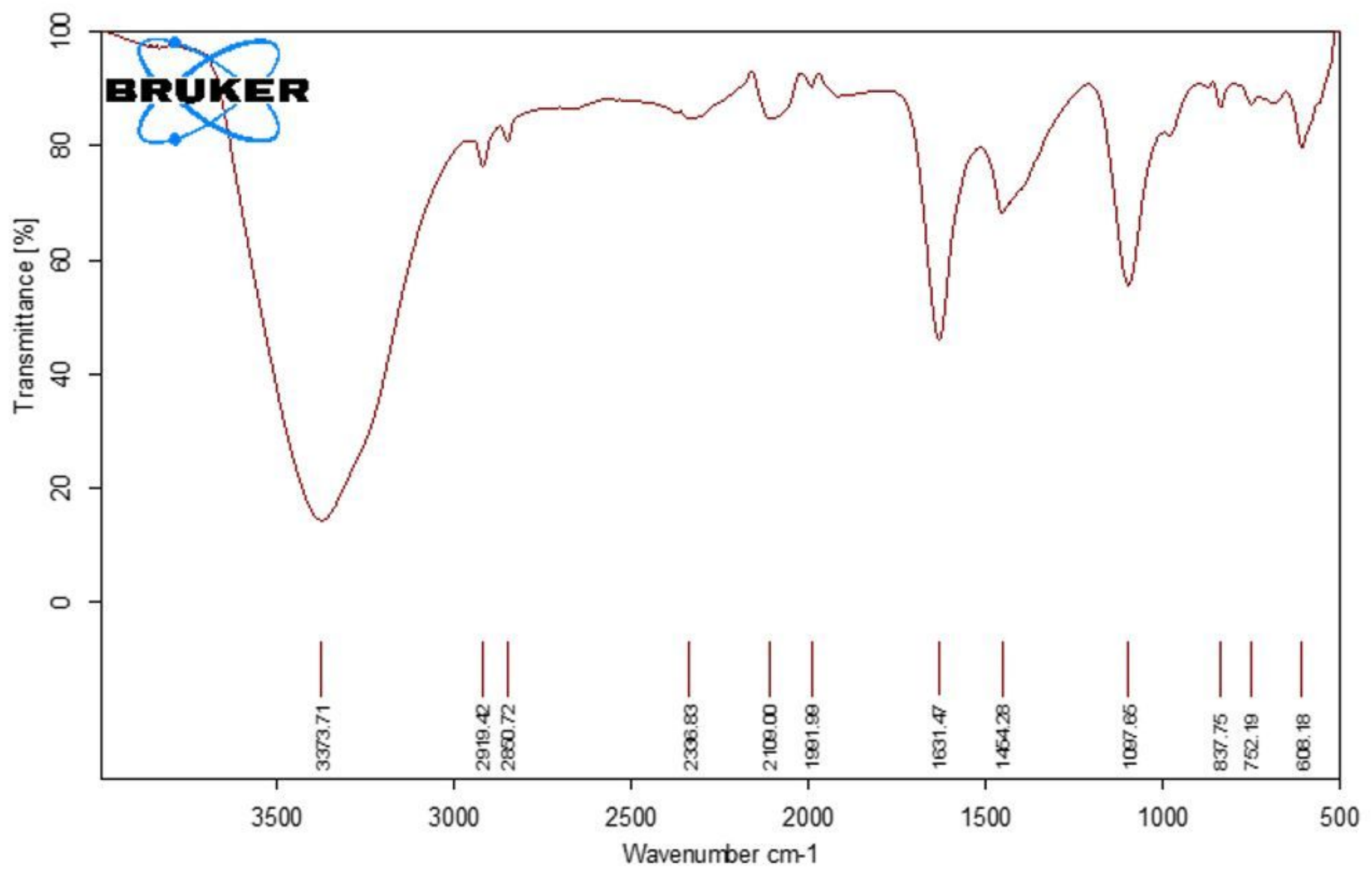

Figure 3

FTIR spectra of $\mathrm{CeO} 2 / \mathrm{ZnO} / \mathrm{GO}$ nanocomposite
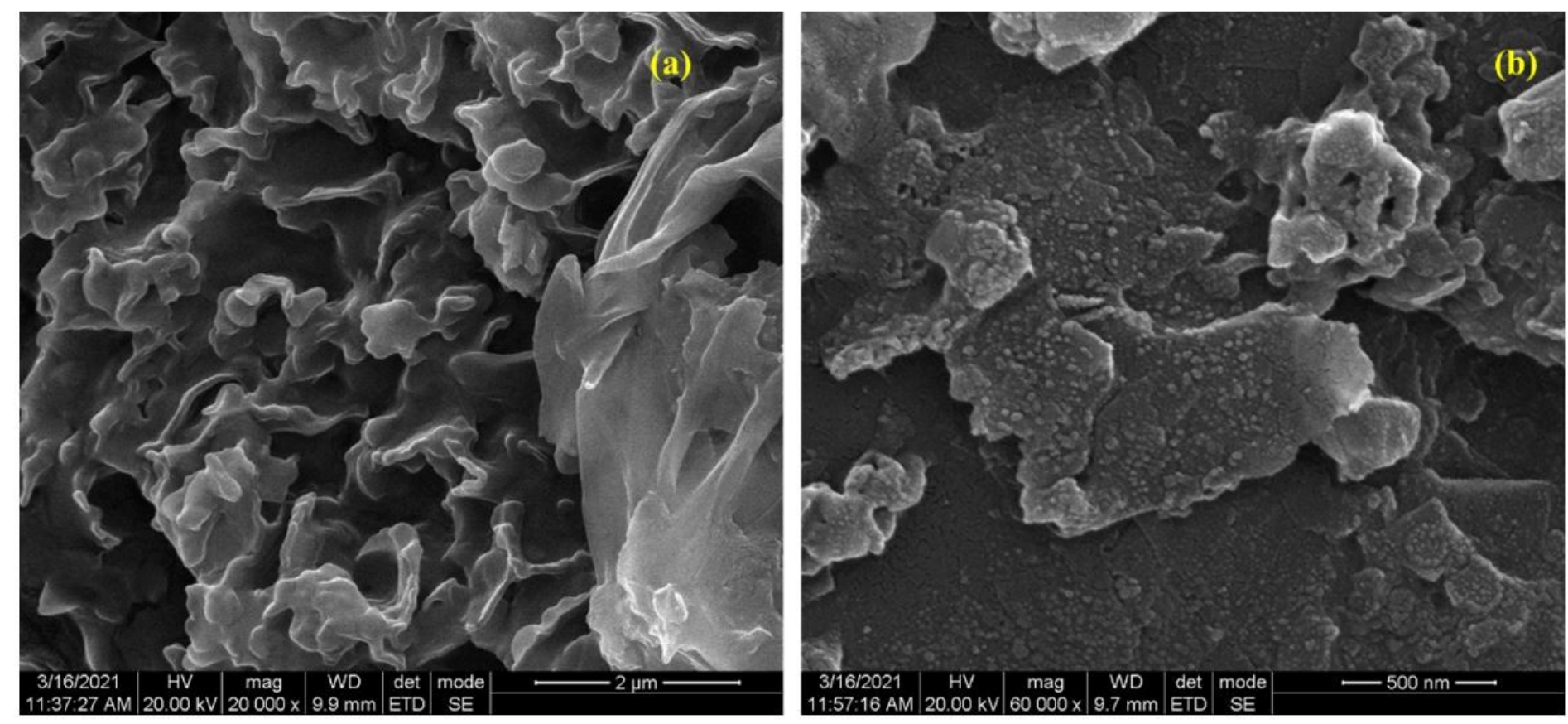

Figure 4 
FE-SEM images of CeO2/ZnO/GO nanocomposite

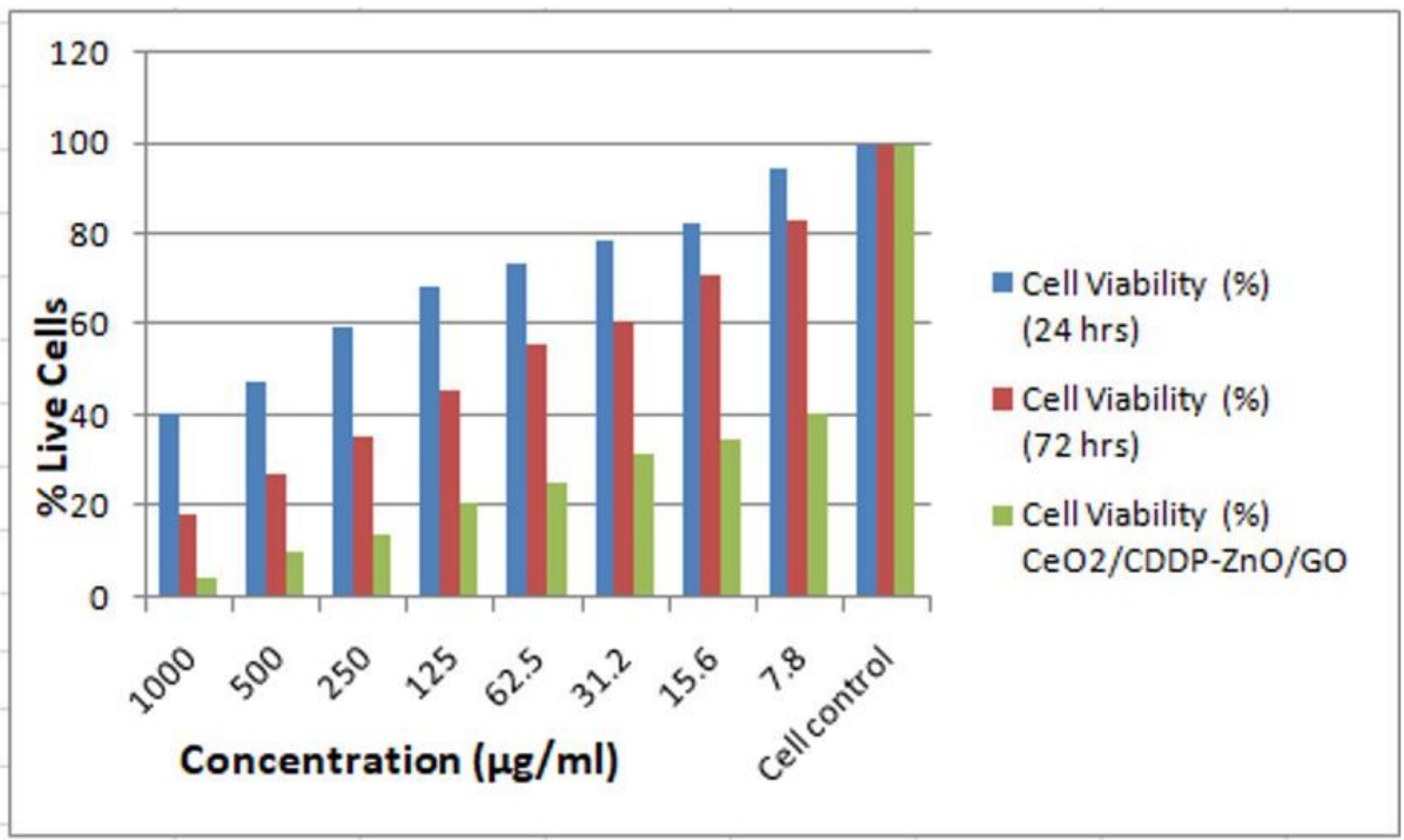

Figure 5

$\%$ Cell Viability of $\mathrm{CeO} 2 / \mathrm{ZnO} / \mathrm{GO} \& \mathrm{CeO} / \mathrm{CDDP}-\mathrm{ZnO} / \mathrm{GO}$ nanocomposite against HeLa Cell Line 


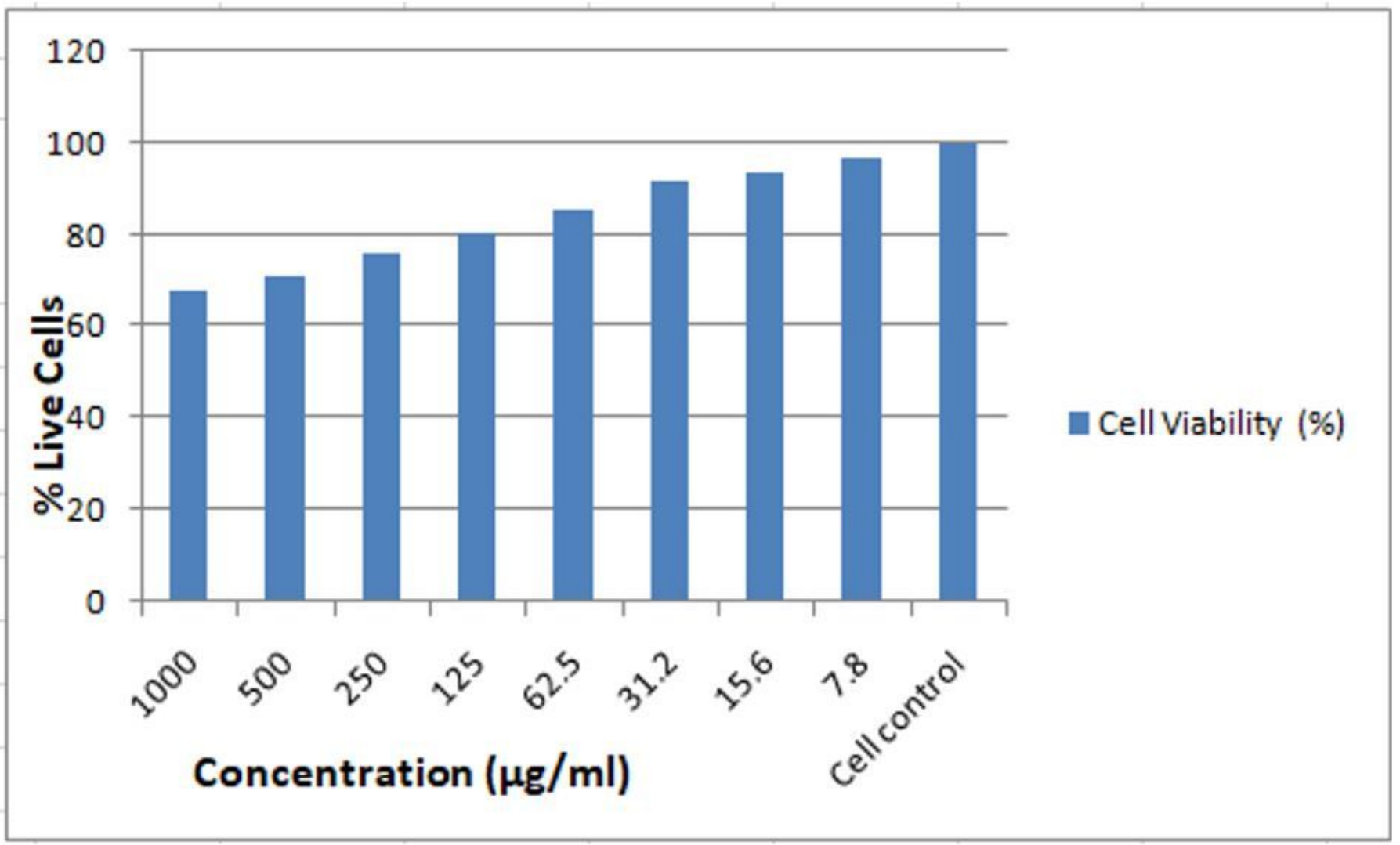

Figure 6

$\%$ Cell Viability of CeO2/ZnO/GO nanocomposite against normal Cell Line. 

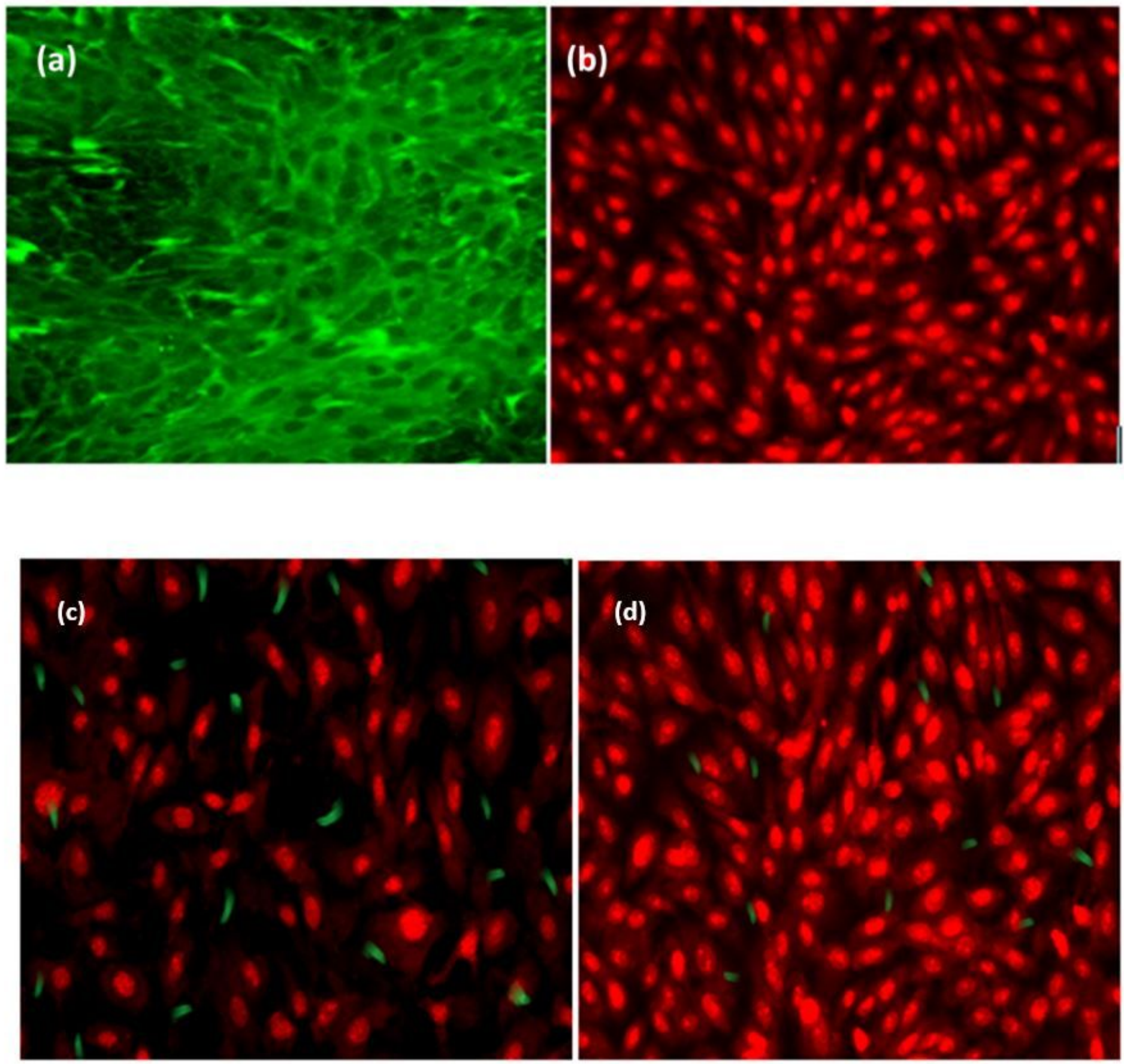

\section{Figure 7}

Microscopic Fluorescence images (a) untreated HeLa cells; (b), (c), (d) treated HeLa cells using $1000 \mu \mathrm{g} / \mathrm{ml}, 500 \mu \mathrm{g} / \mathrm{ml}$ and $250 \mu \mathrm{g} / \mathrm{mlCeO} 2 / \mathrm{ZnO} / \mathrm{GO}$ nanocomposite. 

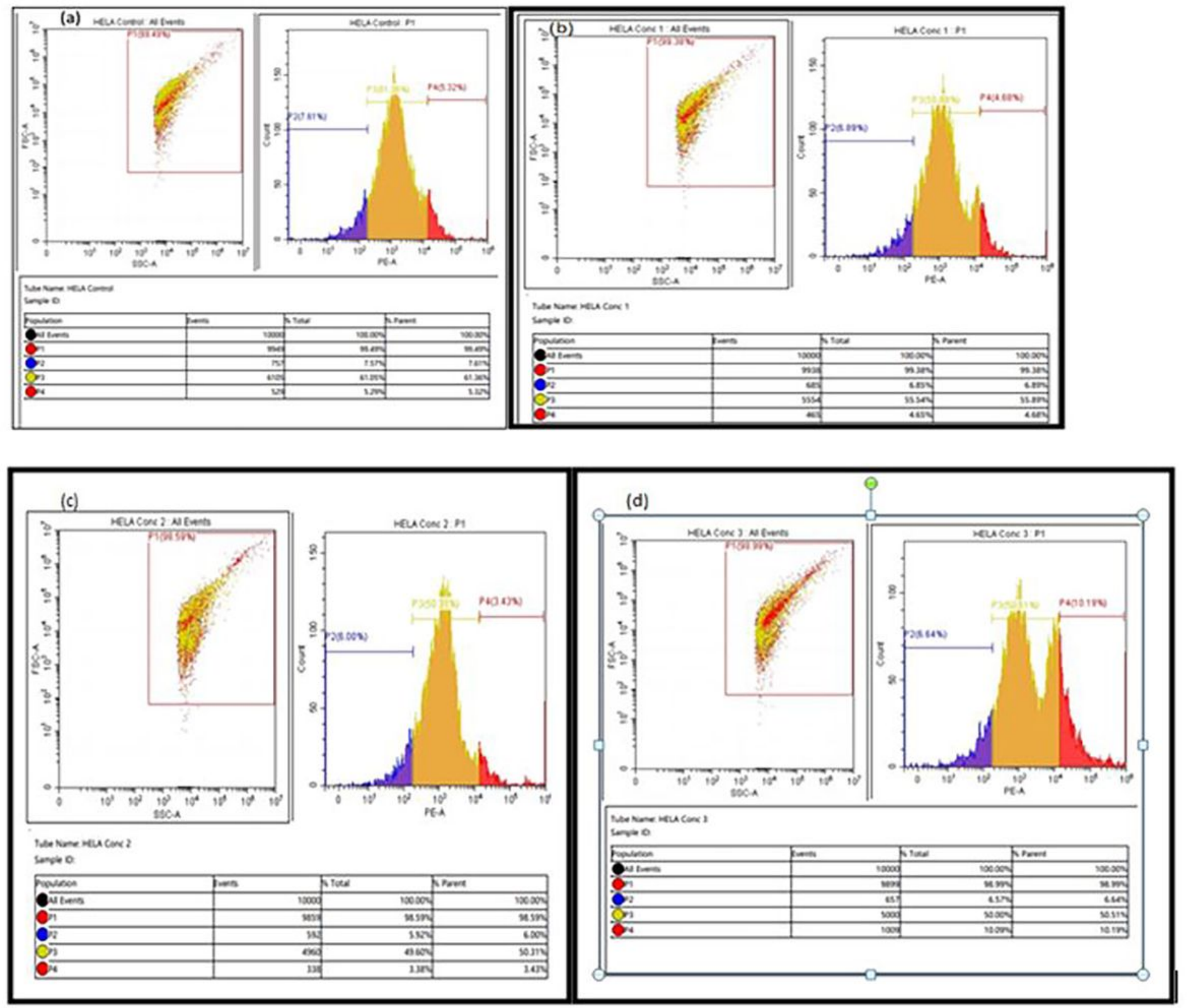

Figure 8

Flow cytometry histogramsof (a) untreated HeLa cells; (b), (c), (d) $125,62.5 \& 31.2 \mu \mathrm{g} / \mathrm{ml}$ of CeO2/ZnO/GO nanocomposite treated with HeLa cells. 